\title{
SOME ULTRASTRUCTURAL SUPERFICIAL CHANGES IN HOUSE FLY (DIPTERA: MUSCIDAE) AND BLOW FLY (DIPTERA: CALLIPHORIDAE) LARVAE INDUCED BY EUCALYPTOL OIL
}

\author{
Kabkaew L. SUKONTASON, Kom SUKONTASON, Noppawan BOONCHU \& Somsak PIANGJAI
}

\begin{abstract}
SUMMARY
The ultrastructural superficial changes in third instar house fly (Musca domestica) and blow fly (Chrysomya megacephala) induced by eucalyptol oil were observed using scanning electron microscopy. Dipped in $0.902 \mathrm{~g} / \mathrm{ml}$ eucalyptol for $30 \mathrm{sec}$, the larvae integument of both species showed significant aberrant appearance of the body surface, particularly swelling integument, bleb formation, partial breach and deformation of spines.
\end{abstract}

KEYWORDS: Fly larvae; Eucalyptol; Ultrastructural changes; Scanning electron microscopy.

\section{INTRODUCTION}

The house fly, Musca domestica L., and blow fly, Chrysomya megacephala (Fabricius), are of medical and veterinary importance worldwide, not only as pestiferous in a human and livestock environment, but also as mechanical carriers of several pathogens (e.g., virus, bacteria, protozoa, helminth eggs) that may cause diseases ${ }^{7}$. Moreover, the effects of facultative myiasis have been recorded ${ }^{3,9,13,19,24}$.

Although the use of insecticides has been mostly reported for fly control, other applications that result in decreased residual for the human/ animal environment should be investigated further. For example, bioinsecticides, which are botanical and based on natural compounds from plants, have been of interest.

Eucalyptus oil is claimed to be safe for humans, and has been used as a medicine and for aromatherapy ${ }^{21}$. It was also approved by the Food and Drug Administration (FDA, USA) as a food [CFR (Code of Federal Regulation $\left.)^{5}\right]$. The major component of eucalyptol oil is eucalyptol or 1,8-cineole. On the other hand, some degree of eucalyptol toxicity has been shown in some medically and/or economically important insects [e.g., triatomine bug, Triatoma infestans; red flour beetle, Tribolium castanaeum; lesser grain borer, Rhyzopertha dominica; rice weevil, Sitophilus oryzae; sawtoothed grain beetle, Oryzaephilus surinamensis; house fly; Hessian fly, Mayetiola destructor; German cockroach, Blattella germanica and stored food mite, Tyrophagus putrescentiae $]^{10-12,17,21}$. Among these, no information concerning the ultrastructural changes after direct contact with eucalyptol has been found. Therefore, to understand the impact of $98 \%$ eucalyptol on fly larval integument, we dipped $M$. domestica and $C$. megacephala larvae into the substance and assessed the ultrastructurally superficial changes.

\section{MATERIALS AND METHODS}

Collection and maintenance of flies: Colonies of $M$. domestica and C. megacephala that originated from adults were collected from markets in Muang district, Chiang Mai province, northern Thailand, by using a sweeping net. They were transferred into a small cage $(16 \times 16 \times 16 \mathrm{~cm})$ and transported to the Department of Parasitology, Faculty of Medicine, Chiang Mai University, for identification and colonization. Adults of both species were reared on two kinds of food: (I) a mixture of $10 \%$ (w/v) multivitamin syrup solution and (II) fresh pork liver as both a food source and oviposition site. Furthermore, $M$. domestica flies were provided with a combination of rice polish, chaff and water at a weight ratio of 2:1:1: and $40 \mathrm{~g}$ of this mixture was placed on a $9 \mathrm{~cm}$ glass plate as a supplementary food and oviposition site. Small pieces of fresh pork liver were changed daily; and a mixture of $10 \%$ sugar solution, multivitamins syrup and the supplementary food were changed every two days. Subsequently, the oviposition sites were observed daily for the presence of eggs; and if present, they were transferred into several $12 \times 15 \times 6 \mathrm{~cm}$ transparent plastic boxes with $40 \mathrm{~g}$ of fresh pork liver provided as larval food. To prevent over-population, each box housed 30 - 40 larvae, and a rectangular lid was cut to $3 / 4$ of the total area and fused together with fine silkscreen material for ventilation. This material also prevented small insects from entering the box to oviposit. The lids were sealed tightly with adhesive paper tape to prevent the larvae from crawling out. Larvae were maintained at an ambient temperature (24 $28^{\circ} \mathrm{C}$ ) in a cabinet at the rearing room of the Department of Parasitology. Liver was replaced daily until some third instar developed into pre-pupa, the non-feeding period. Boxes containing pupae were covered and tightly sealed until some pupae emerged as adults, after which the boxes were placed into a rearing cage and the adults released. The next generation of flies was reared in the same manner as previously described. 


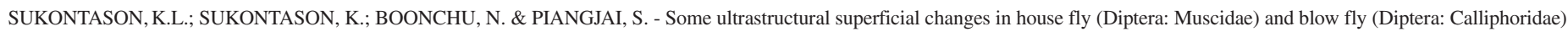
larvae induced by eucalyptol oil. Rev. Inst. Med. trop. S. Paulo, 46(5):263-267, 2004.

The third instar $M$. domestica and $C$. megacephala used in this experiment were 3-day-old after hatching from the same egg batch. Larvae were applied with commercial eucalyptol using the dipping method $^{14}$. This eucalyptol was produced for R\&D (Research and Development) use only, and not for drug, household or other uses. Its properties were $98 \%$ purity and $0.92 \mathrm{~g} / \mathrm{ml}$ of density.

Dipping method: Thirty larvae of each species were randomly selected from the rearing boxes and wrapped with voile cloth. They were gently dipped into eucalyptol $(100 \% \mathrm{v} / \mathrm{v}$ or $0.902 \mathrm{~g} / \mathrm{ml})$ for exactly 30 sec, whereas those of a control group were dipped in absolute ethanol. Only those dead in the treated group were selected for scanning electron microscopy (SEM) processing. In the controls, some of those alive after dipping were randomly selected for the SEM process.

Scanning electron microscopy: Larvae of both groups were prepared for the SEM by fixing with $2.5 \%$ glutaraldehyde in phosphate buffer (pH 7.4) at $4{ }^{\circ} \mathrm{C}$ for $24 \mathrm{~h}$. They were then rinsed with phosphate buffer (two times with a 10-min interval). The rinsed larvae were post-fixed in $1 \%$ osmium tetroxide at room temperature for $2-3 \mathrm{~h}$. After rinsing two times with phosphate buffer, they were dehydrated in an increasing series of concentration of alcohol at $12 \mathrm{~h}$ intervals. In the last step of dehydration, acetone was applied instead of absolute ethanol twice, with a 30-min interval. The critical point drying was performed thereafter. These specimens were attached to brass holders, using carbon twocomponent glue. They were coated with gold in a high-vacuum sputtering apparatus and stored in a desiccator until use. The specimens were observed with a JEOL-JSM840A scanning electron microscope (Japan).

\section{RESULTS}

After being dipped for $30 \mathrm{sec}$ in eucalyptol, house fly larvae exhibited remarkably aberrant appearances (Figs. 1-3). Extensive swelling of the integument (Fig. 1) and the varied size of bleb formation (Fig. 2) was evident in most specimens examined. The posterior spiracles, located centrally at the end of the abdominal segment, were coated with thick residuum (Fig. 3), with the original features hardly recognizable. In contrast, the surface architecture of the control specimens, which had been dipped in absolute ethanol, appeared normal, having a smooth integument (Figs. 4,5), well-organized spines (Fig. 5) and a distinct "Dshaped" posterior spiracle including spiracular slits and posterior spiracular hairs (Fig. 6). Regarding the treated C. megacephala larvae, their morphological features appeared similarly aberrant to those of $M$. domestica (Figs. 7-10). Not only was the widespread swelling of integument markedly observed, but also some parts of the body looked corroded (or sloughing), appearing in various sizes of protrusion with a raised edge (Figs. 7,8). The intersegmental spines were swollen in an irregular shape; while many breaches occurred in some surface areas (Fig. 9). Thick material was observed by coating the posterior spiracle (Fig. 10). Control larvae were normal in their morphological architecture, such as smooth integument or well-shaped intersegmental spines (Figs. 11,12).

\section{DISCUSSION}

This study has shown that eucalyptol causes severe deformation to the integument of dipped fly larvae. Bleb formation, breached integument and deformation of intersegmental spines were the striking phenomena; and these were similarly observed in the larvae of both species. None of the above phenomena were found in the controls. Why these alterations occurred is still unknown. However, histopathological study on the plant extract (Eichhornia crassipes) against larvae of mosquito, Culex pipiens (Diptera: Culicidae), revealed drastic effect on integument, as well as larval midgut, fats and muscles ${ }^{2}$. Similarly, the SEM investigation of the plant extract of Kaempferia galanga demonstrated the damage of surface morphology on Culex quinquefasciatus larvae ${ }^{8}$. For bleb formation, phenomenon observed in this study was similar to those previous works, but occurring in the intestinal parasites administrated with antiparasitic drugs. In helminths, for example, blebbing, swelling, erosion and disruption of the integument occurred on the surface of trematodes such as the liver fluke, Opisthorchis viverrini, after in vitro incubation in praziquantel $^{1}$, and the colchicine or cytochalasin $\mathrm{B}$, as determined by SEM and transmission electron microscopy (TEM $)^{20}$. These corresponded with the effects of fasciolicide "clorsulon" on the integument of the liver fluke, Fasciola hepatica ${ }^{15}$. The treated cestode, Taenia taeniaeformis, with mebendazole, demonstrated the degeneration of tegument with grooves, holes, and crater-like structures ${ }^{22}$. Similarly, in other groups of medically important helminths, the topographic changes of the nematode, Capillaria hepatica, were in the form of a disorganized cuticle with absence of surface uniformity ${ }^{6}$. The formation of bleb and loss of integument organization might be caused by the "stress responses" resulting from any harmful condition ${ }^{17}$.

The delivery mode of eucalyptol is still unclear. PRATES et al. ${ }^{17}$ reported that the main action was contact and/or ingestion. On the other hand, the principal result of action was reported in the vapor phase $e^{4,18,23}$. In our study, the dipping method was used to evaluate the effect of eucalyptol on ultrastructural change of larval integument. It is not possible to point out whether the cause of larval death is from direct contact eucalyptol that causes ultrastructural changes to the integument, or the consumption or vapor action of eucalyptol. Our study provides evidence that when fly larvae contact eucalyptol, some die, and superficial alterations to the integument have been ultrastructurally found.

\section{RESUMO}

\section{Algumas alterações ultraestruturais superficiais nas larvas da mosca doméstica (Diptera: Muscidae) e da mosca varejeira (Diptera: Calliphoridae) induzidas pelo óleo de eucalipto}

Alterações ultraestruturais superficiais no terceiro estágio da mosca doméstica (Musca domestica) e da mosca varejeira (Chrysomya megacephala) induzidas pelo óleo de eucalipto foram observadas usandose microscopia eletrônica de varredura. Imersos em 0,902 g/ml de óleo de eucalipto durante 30 segundos os tegumentos das larvas de ambas espécies mostraram aparência aberrante significativa da superfície corporal, particularmente edema do tegumento, formação de bolhas, fenda parcial e deformação das espículas.

\section{ACKNOWLEDGMENT}

We thank the Faculty of Medicine Endowment Fund for Medical Research, Faculty of Medicine, Chiang Mai University, for financial support. A part of this research has been supported by the Kazato Research Foundation, Japan. 

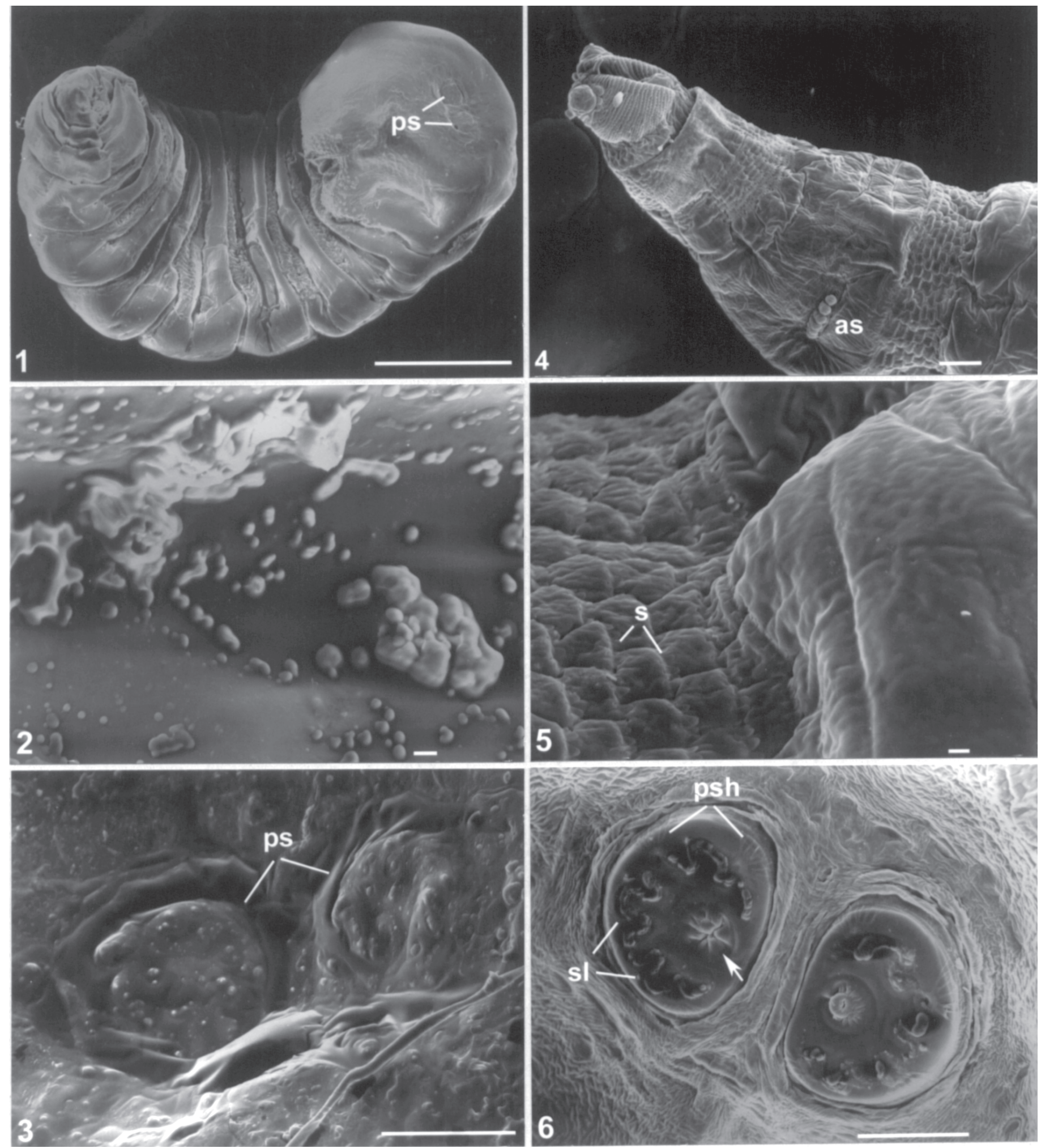

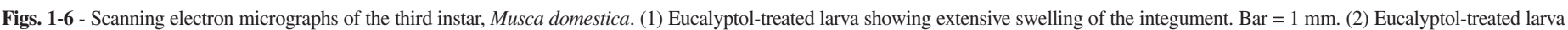

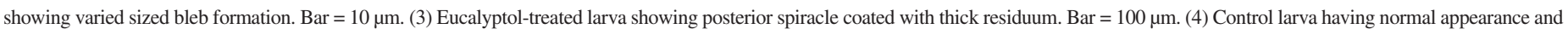

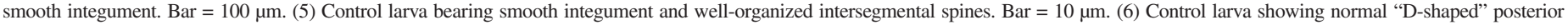
spiracle, spiracular slits and posterior spiracular hairs. Bar $=100 \mu \mathrm{m}$. Abbreviation: as, anterior spiracle; ps, posterior spiracle; psh, posterior spiracular hairs; $\mathrm{s}$, spines; sl, slits. 


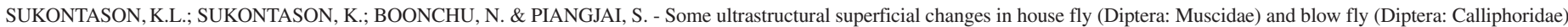
larvae induced by eucalyptol oil. Rev. Inst. Med. trop. S. Paulo, 46(5):263-267, 2004.
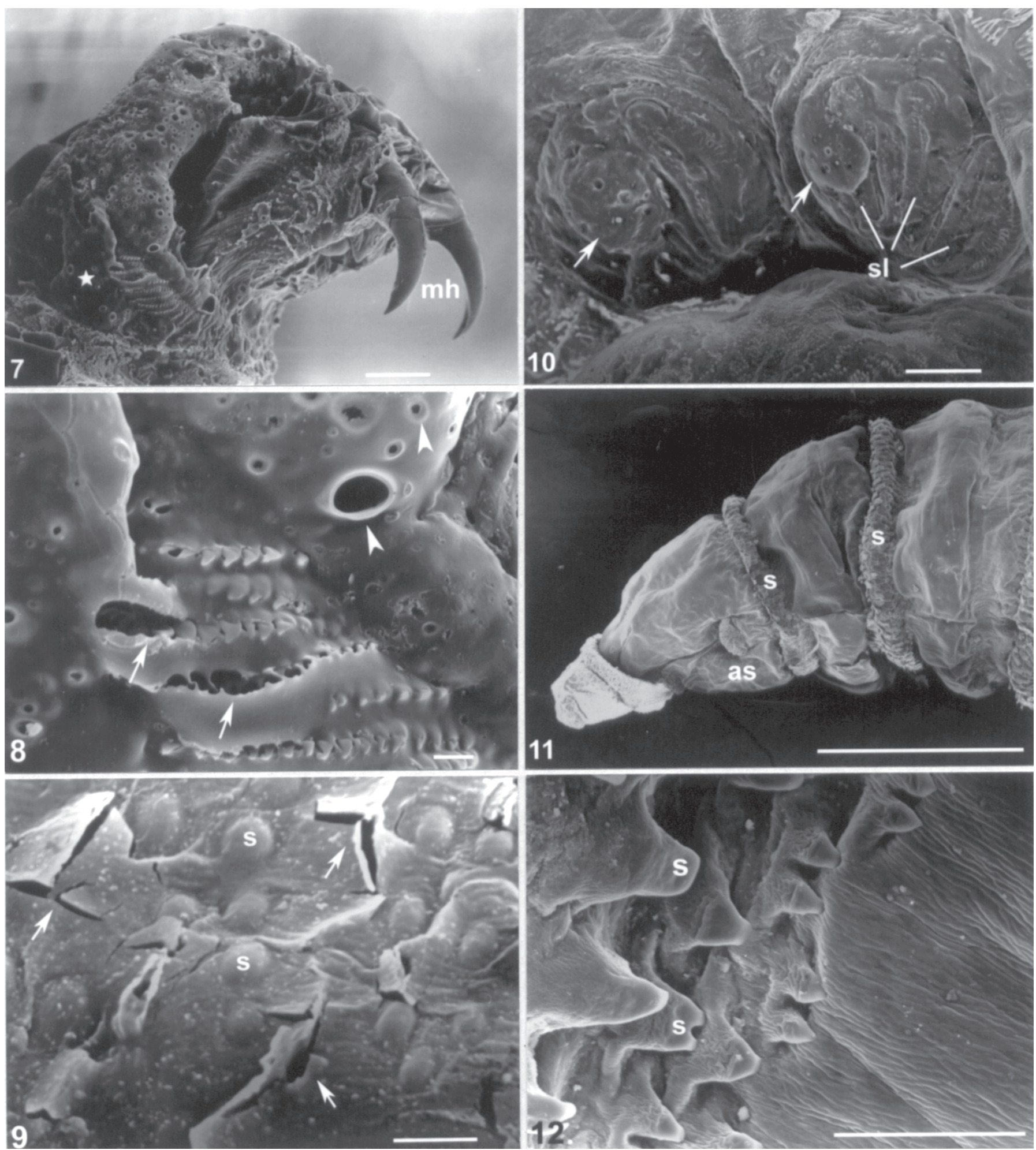

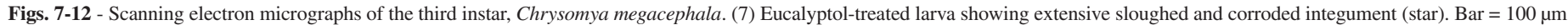

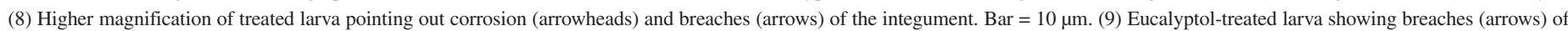

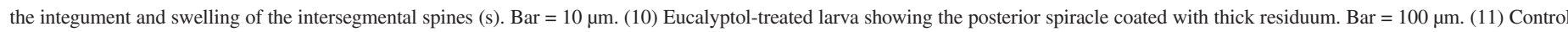

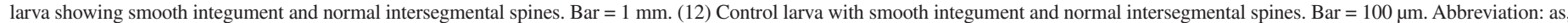
anterior spiracle; mh, mouthhook; s, spines; sl, slits. 


\section{REFERENCES}

1. APINHASMIT, W. \& SOBHON, P. - Opisthorchis viverrini: effect of praziquantel on the adult tegument. Southeast Asian J. trop. Med. publ. Hlth, 27: 304-311, 1996.

2. ASSAR, A.A. \& EL-SOBKY, M.M. - Biological and histopathological studies of some plant extracts on larvae of Culex pipiens (Diptera: Culicidae). J. Egypt. Soc. Parasit., 33: $189-200,2003$.

3. BURGESS, I. \& DAVIES, E.A. - Cutaneous myiasis caused by the housefly, Musca domestica. Brit. J. Derm., 125: 377-379, 1991.

4. CHOI, W.I.; LEE, E.H.; CHOI, B.R.; PARK, H.M. \& AHN, Y.J. - Toxicity of plant essential oils to Trialeurodes vaporariorum (Homoptera: Aleyrodidae). J. econ. Entomol., 96: 1479-1484, 2003.

5. DE VINCENZI, M.; SILANO, M.; DE VINCENZI, A.; MAIALETTI, F. \& SCAZZOCCHIO, B. - Constituents of aromatic plants: eucalyptol. Fitoterapia, 73: 269-275, 2002.

6. EL GEBALY, M.W.; NASSERY, S.F.; EL AZZOUNI, M.Z.; HAMMOUDA, N.A. \& ALLAM, S.R. - Effect of mebendazole and ivermectin in experimental hepatic capillariasis: parasitological, scanning electron microscopy and immunological studies. J. Egypt. Soc. Parasit., 26: 261-272, 1996.

7. GREENBERG, B. - Flies and disease. V. II. Biological and disease transmission. New Jersey, Princeton University Press, 1973.

8. INSUN, D.; CHOOCHOTE, W.; JITPAKDI, A. et al. - Possible site of action of Kaempferia galanga in killing Culex quinquefasciatus larvae. Southeast Asian J. trop. Med. publ. Hlth, 30: 195-199, 1999.

9. KUMARASINGHE, S.P.W.; KARUNAWEERA, N.D. \& IHALAMULLA, R.L. - A study of cutaneous myiasis in Sri Lanka. Int. J. Derm., 39: 689-694, 2000.

10. LAMIRI, A.; LHALOUI, S.; BENJILALI, B. \& BERRADA, M. - Insecticidal effects of essential oils against Hessian fly, Mayetiola destructor (Say). Field crops Res., 71: 9-15, 2001.

11. LAURENT, D.; VILASECA, L.A.; CHANTARAINE, J. et al. - Insecticidal activity of essential oils on Triatoma infestans. Phytotherapy Res., 11: 285-290, 1997.

12. LEE, S.; PETERSON, C.J. \& COATS, J.R. - Fumigation toxicity of monoterpenoids to several stored product insects. J. stored Prod. Res., 39: 77-85, 2003.
13. MAGNARELLI, L.A. \& ANDREADIS, T.G. - Human cases of furuncular, traumatic, and nasal myiasis in Connecticut. Amer. J. trop. Med. Hyg., 30: 894-896, 1981.

14. MATSUMURA, F. - Toxicology of insecticides. New York, Plenum, 1985.

15. MEANEY, M.; FAIRWEATHER, I.; BRENNAN, G.P. \& FORBES, A.B. - Transmission electron microscope study of the ultrastructural changes induced in the tegument and gut of Fasciola hepatica following in vivo drug treatment with clorsulon. Parasit. Res., 92: 232-241, 2004.

16. PÉREZ-SERRANO, J.; CASADO, N.; DENEGRI, G. \& ROGRIGUEZ-CAABEIRO, F. - The effects of albendazole and albendazole sulphoxide combination therapy on Echinococcus granulosus in vitro. Int. J. Parasit., 24: 219-224, 1994.

17. PRATES, H.T.; SANTOS, J.P.; WAQUIL, J.M. et al. - Insecticidal activity of monoterpenes against Rhyzopeertha dominica (F.) and Tribolium castaneum (Herbst). J. stored Prod. Res., 34: 243-249, 1998.

18. SÁNCHEZ-RAMOS, I. \& CASTAÑERA, P. - Acaricidal activity of natural monoterpene on Tyrophagus putrescentiae (Schrank), a mite of store food. J. stored Prod. Res., 37: 93-101, 2001

19. SEHGAL, R.; BHATTI, H.P.S.; BHASIN, D.K. et al. - Intestinal myiasis due to Musca domestica: a report of two cases. Jap. J. infect. Dis., 55: 191-193, 2002.

20. SOBHON, P. \& APINHASMIT, W. - Opisthorchis viverrini: the effects of colchicine and cytochalasin B on the adult tegument. Southeast Asian J. trop. Med. publ. Hith, 27: 312-318, 1996.

21. TRIPATHI, A.K.; PRAJAPATI, V.; AGGARWAL, K.K. \& KUMAR, S. - Toxicity, feeding deterrence, and effect of activity of 1,8-cineole from Artemisia аппиа on progeny production of Tribolium castanaeum (Coleoptera: Tenebrionidae). J. econ. Entomol., 94: 979-983, 2001.

22. VERHEYEN, A.; VANPARIJS, O.; BORGERS, M. \& THIENPONT, D. - Scanning electron microscopic observations of Cysticercus fasciolaris (= Taenia taeniaeformis) after treatment of mice with mebendazole. J. Parasit., 64: 411-425, 1978.

23. YANG, Y.C.; CHOI, H.Y.; CHOI, W.S.; CLARK, J.M. \& AHN, Y.J. - Ovicidal and adulticidal activity of Eucalyptus globulus leaf oil terpenoids against Pediculus humanus capitis (Anoplura: Pediculidae). J. Agric. food Chem., 52: 2507-2511, 2004.

24. ZUMPT, F. - Myiasis in man and animals in the old world. London, Butterworth, 1965.

Received: 22 March 2004

Accepted: 20 September 2004 